\title{
The Evaluation of Tourism Marketing Model within Moroccan Public Policy Management
}

\author{
By Yassir Lamnadi*
}

\begin{abstract}
Morocco is situated in the north western Africa facing Europe on the Mediterranean and on the other side open to the Atlantic Ocean benefiting from a favourable geographical location as Africa's gate to Europe. The country has four inscribed biosphere reserves, and nine UNESCO inscribed world heritage sites. The performance of tourism in the country kept a steady growth rate in the last decade despite being slightly affected by the 2008 world economic crisis; just to recover later by taking advantage of the unstable political situation in competing neighbour countries, after the so-called 'Arab Spring'. This improvement in the performance of the Moroccan tourism sector is also among the planned objectives of the two major tourism management plans in modern Morocco (Vision 2010 and Vision 2020). Evidently, the second strategic plan (2020) came as a continuation of the first one but with wider plans and bigger ambition. However, these management plans were not all 'la vie en rose'. The objectives of both programs were not completely achieved (2020 vision is still two years away from completing its execution but various gaps can be found in the realised points). A descriptive study was conducted to evaluate the performance of the tourism marketing practices within Moroccan public policy management. The tourism marketing strategy of both management programs was critically reviewed to identify both their strengths and weaknesses. The findings of this study show that public policy concerning tourism sector drove the country in the right development path but still, the chosen marketing strategies were not highly efficient, given the considerable various Moroccan tourism potential. Nevertheless, analysis also showed that public tourism management policy was initially designed with some inadequate approaches concerning the development of the sector. It has been suggested that the government should concentrate more on a wider marketing approach that takes into consideration the valorisation of the sustainable tourist product of the country and more importantly empowering the human potential to be centric in parallel with the touristic product.
\end{abstract}

Keywords: Morocco, public policy, tourism, tourism marketing, Vision 2020.

\section{Introduction}

As an industry, tourism is based on the supply and demand, and, obviously, a marketing policy is required in order to have a clear business vision and continuity. A good and efficient marketing policy also opens up new opportunities for the destination product to reach new potential markets and keep it operating in the long run. Usually, public agents such as tourism ministries, especially in third world countries, undertake the promotion of a country's destination. The sector's structure defines the efficiency of the marketing policy. However, there is usually a difference in managing marketing policy between private and public

${ }^{*}$ Phd Candidate, Universitat Rovira I Virgili, Spain. 
stakeholders. It depends on the available resources, destination perceptions, and target markets. In Morocco, one cannot find many differences between public and private marketing policies. In both cases, similar promotion channels and techniques are used.

As shown in Figure 1, Morocco had 11.35 million tourist arrivals in 2017 which makes it the first destination of Africa in terms of tourists' arrivals and the third in tourism receipts after South Africa and Egypt (UNWTO 2017). These figures reflect strong growth in the last ten years. It has maintained a growth line despite the recent political turbulence that has affected other North African tourist countries, especially Tunisia and Egypt. The latter has traditionally been the main tourist destination in Africa. At present tourism has a significant influence on the Moroccan economy. Between 2010 and 2013, revenues generated by international tourism accounted for $6.5 \%$ of GDP (UNWTO 2014). In summary, the last fifteen years Morocco has experienced a significant change in the economic structure with tourism being the main factor of economic development.

Figure 1. The Evolution of Tourist Arrivals to Morocco

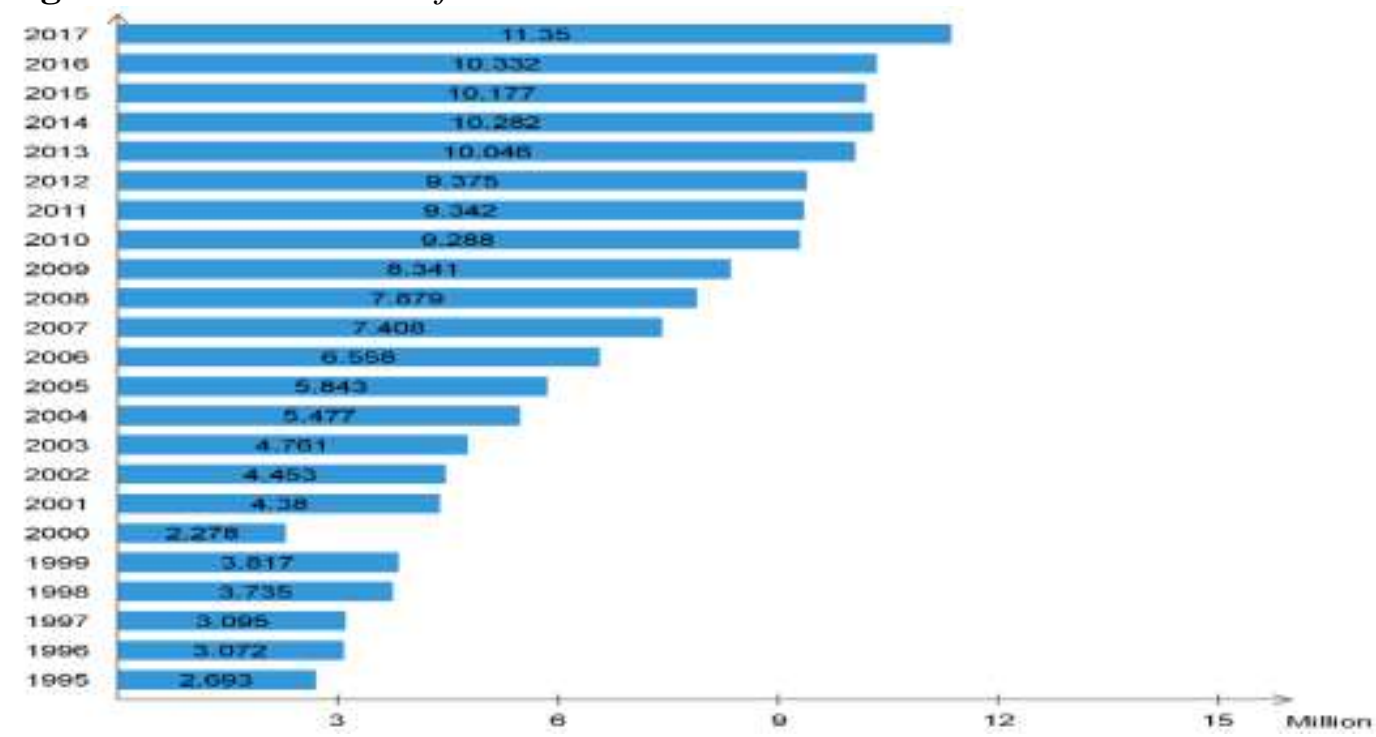

Source: Elaborated by author based on Tourism Ministry data.

However, this change in the structure of the economy might have led, in some cases, to an excessive capital production (capital accumulation). This excess capital has created a new challenge for the authorities to maintain its profitability without inflation. Some official studies, which were carried out by the government, suggested that one effective solution for this situation could lay in creating more tourist-residential housing that generates much higher return rates than the conventional hotel activity. The creation of these small-scale tourist accommodations will help the state to solve effectively the capital accumulation problem.

Management plans such as Vision 2010 and 2020 (Ministère du Tourisme 2001, Ministère du Tourisme 2010) are considered to be a perfect fit for such measures. The overall achievement rates of the drawn objectives for both plans 
show some significant successes. The important increase in tourists arrivals, (Africa's first destination), tourism receipts (more than $\$ 7,000$ million in 2014) or the jobs created (about 500,000 direct jobs) (UNWTO 2015, Observatoire du Tourisme 2015); are very important results. Nevertheless, the profitability for the State is questionable, if all the economic costs are taken into account, even more so if we consider the environmental and social costs.

\section{Methodology}

This paper uses secondary sources of data to analyse the Moroccan tourism marketing strategy. The collected data consisted of governmental reports and studies, tourism sector statistics, and different scientific articles and studies addressing the Moroccan tourism sector in general and specifically its marketing strategies. These data were also used to form a descriptive profile of the Moroccan tourism sector for the unfamiliar readers of the country's tourism sector. In addition, the concept and definition of tourism marketing are reviewed in order to build a coherent conceptual framework for the paper. The collected data were analysed and categorised into data sets (codes, categories and sub-categories) according to the nature and function of each variable in this paper. The main data set categories were assigned to texts themed on tourism marketing for the texts dealing with the country's marketing strategies/policies. Connected to this category, other sub-categories were assigned for texts highlighting marketing actors, marketing channels and marketing techniques. Codes were created within the sub-categories to evaluate the nature and function of each single component. The same process was carried out concerning public management data set category and connected sub-categories. Some resource illustrations had to be modified or re-elaborated without affecting its viability or significance.

\section{Concepts and Definitions}

The Chartered Institute of Marketing (CIM) of UK defines marketing as a management process responsible for identifying, anticipating and satisfying customer requirements at a profit. Kotler (2000) defines it as a set of activities directed at facilitating exchanges. In 1988, he refined the definition to the business function that identifies current unfulfilled needs and wants, defines and measures their magnitude, determines which target the organization can best serve and programs to serve these markets.

Lumsdon (1997) defines it as the managerial process of anticipating and satisfying the existing and the potential visitors' needs more effectively compared to competitors; tourism promotion is defined as the process designed to inform potential visitors about the tourism product offered, sharing with them the most attractive and innovative attributes. This process is usually integrated with distribution and implies communication activities including advertising. Promotion and marketing communication strategies are used by tourism destinations to 
influence destination image (Beerli and Martín 2004). For this, different media information and communication technology (narratives/visuals) are deployed to promote a destination image in the market (Govers et al. 2007). Gallarza, et al. (2002) define a destination image as a complex concept, which is open to different interpretation and as lacking a unique meaning.

The portrayal of destination image has been always affected by various objective and subjective factors. It is, principally, feeding on the information available on that certain destination. This information has many sources including promotion (advertising and brochures), the opinions of others (family/friends, travel agents), media reporting (newspapers, magazines, television news reporting and documentaries) and popular culture (motion pictures, literature). Nevertheless, Echtner and Ritchie (2003) point out that this information is always manipulated by visitors' first hand impression: "Furthermore, by actually visiting the destination, the image will be affected and modified based upon first-hand information and experience". Another approach was introduced by Gallarza et al. (2002) by stating that despite the fact that tourism services are intangible, images become more important than reality; and the tourism destination images projected in information space will greatly influence the destination images as perceived by consumers. Tasci and Gartner (2007) present a review of destination image formation based on the works of (Alhemoud and Armstrong 1996, Bramwell and Rawding 1996, Court and Lupton 1997, Gartner 1993, Gunn 1972, and Young 1999 as cited in Tasci and Gartner (2007)). They conclude that image formation is defined as a construction of a mental representation of a destination on the basis of information cues delivered by the image formation agents and selected by a person.

This destination image research line was initially approached in two different ways: empirical studies that apply statistical instruments without developing theoretical frameworks; (Schroeder 1996 as cited in (Gallarza et al. 2002)). The other approach consisted of empirical studies that address image measurement problems while presenting methodological explanation (Carmichael 1992, Echtner and Ritchie 1993, Reilly 1990 as quoted in (Gallarza et al. 2002)). They classified destination image as a variable depending on various factors contributing to the formation of the destination image (Tasci and Gartner 2007).

Baloglu and MacCleary (1999) state that "image is mainly caused or formed by two major forces: stimulus factors and personal factors. The former are those that stem from the external stimulus and physical object as well as previous experience. Personal factors on the other hand, are the characteristics (social and psychological) of the perceiver". This formation process is addressed by two different approaches (Gallarza et al. 2002). A static one that studies the relationship between image and tourist behaviour; and a dynamic one that deals with the structure and formation of the destination image itself.

It is important to note here that tourism promotion is not a standalone factor within the destination image building process. Rather, it depends on other information sources that are projected about the destination influencing its final built image. Moreover, the variables affecting the destination image are various and can differ in type and nature; such as destination preference and visitation 
intention; destination familiarity and the impact of previous visitation; tourists' geographical locations; trip purpose; situational or temporal influences; the image as projected by the destination; and tourists' sociodemographic variables (Govers et al. 2007).

The image of a destination, its formation process controlled or formed by various components, is seen by a large part of literature as dynamic rather than static. Gallarza et al. (2002) point out that this dynamism depends on variables such as distance, residents and, most importantly, time and space. Moreover, the interaction between these variables can occur on three dimensions: measuring subject's perception, objects and destinations, and image attributes and characteristics. The time variable can affect image in three different ways: length of stay in image destination, time interval between repeated visits to the same destination and the effect of previous visitation on image formation (Gallarza et al. 2002). Similarly, the space variable influences the image formation process depending on where the visit occurs and the study circumstantiality (Gallarza et al. 2002). Given the fact that the inter-relationships between these variables influence the destination image, it consequently affects the visitors' satisfaction level, as well, through a set of dependencies. Decrop (1999) as quoted in (Del Bosque and San Martin 2008) suggests that the effect of image variables on the consumer behaviour in tourism is what defines the satisfaction level. He, also, states that the cognitive and emotional approaches are highly adequate for analysing tourist decision making and behaviour processes.

In the same sense, these variables surrounding the destination ought to be rooted in any destination image promotion to portray a 'true destination identity'. Therefore, this identity is reflected in the actual tourism experience and the impression which the visitor is left with and this affects the tourist satisfaction (Govers and Go 2004). However, Echtner and Prasad (2003) note that, in this context, two significant gaps could occur if a) the tourism product and the way is promoted are not convenient with the destination's identity, or b) when the destination image is idealistically perceived through promotion causing unrealistic expectations to the tourist.

Despite the considerable progress carried out by researchers in the tourism marketing field, yet such a field is perceived to be too narrow. Most of the studies presented in this paper tend to focus on specific topics within tourism marketing literature such as destination image, internet marketing, and market segmentation. Moreover, there are, still, a number of areas, within tourism marketing literature, which have not been acknowledged or managed, due to unclear motives and are ignored by scholars contributing to this discipline of tourism research. These ambiguities may reflect gaps in the theoretical understanding of tourism marketing causing, consequently, bigger gaps between tourism research and real world practices. However, in parallel with the progress of tourism industry, general marketing theories also achieved considerable progress. Presently, the way that tourism marketing is taught and researched has been widely criticised for being done as in 1960s, but patched with decorations such as services, relationships and e-businesses. This urges a pressing need for reinventing marketing theories to fit the present and the future (Gummesson 2002). 


\section{Findings/Results}

\section{Promotion Actors}

In Morocco, the main tourism agent is the ONMT (Office National Marocain $\mathrm{du}$ Tourism), a public administration created in 1918 in charge of the promotion and marketing of the product 'Morocco' on the national and international level. The Office plans promotion strategies as a public stakeholder, as it has become a statuary branch of the Tourism Ministry. However, it may include in its promotion strategy some of the private stakeholders as well, as a collaboration policy between public and private sector. For instance, during the last two decades, many promotion projects were implemented along with some private actors such as travel agencies, real estate investors etc. Other public/private collaborations may be involved at different levels in this promotion process (Figure 2).

Figure 2. Structure of Moroccan Tourism Promotion

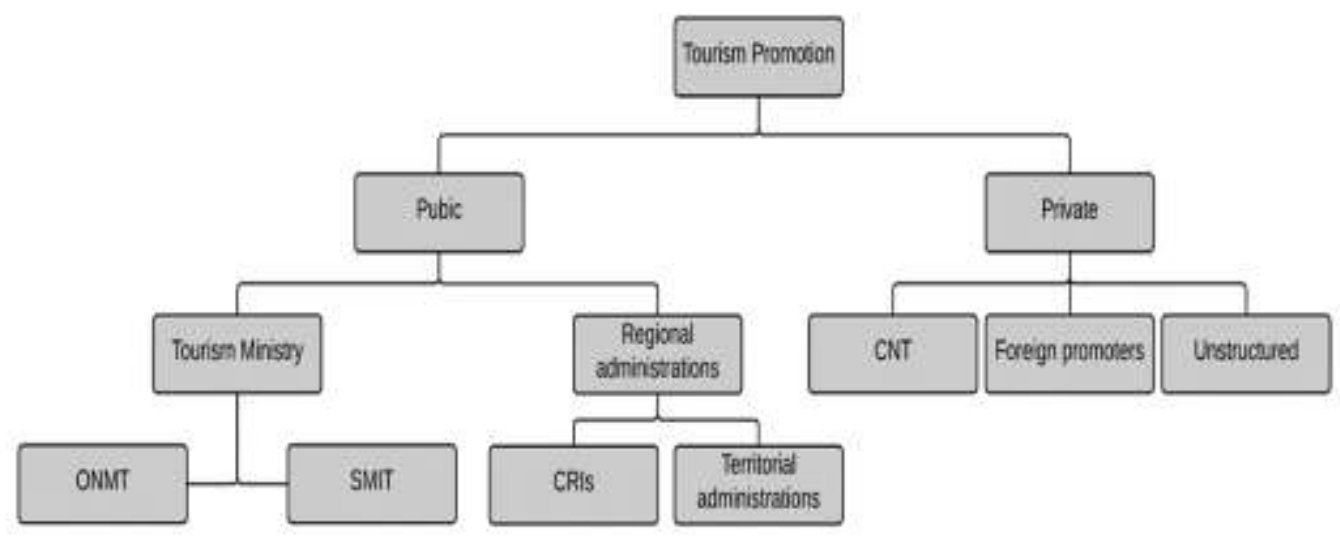

Source: Author.

\section{The Tourism Ministry}

The governmental administration is mainly supervising the tourism sector in the country, which defines itself as the governmental authority in charge of tourism. Its main mission is to elaborate and implement the government policy concerning the tourism sector and related aspects. It is designated with the following mission:

Develop, implement and evaluate the tourism development strategy.

Conduct studies and necessary surveys for the development of tourism at both national and regional level.

Develop draft laws and organizational texts relating to tourism activities and ensure their application.

Supervise and support tourism professions and activities in accordance with the reinforced regulations. 
Orientate, control the deconcentrated services and evaluate the necessary means for their management.

Participate in the development and management of the hotel and tourism training strategy.

Supervise training institutions under the Ministry of Tourism (Figure 3);

$>$ Ensure the establishment and strengthening of relations in the framework of bilateral cooperation as well as with specialized organizations.

Ensure the guardianship of institutions under the Ministry of Tourism.

In addition to the centrality nature of developing management plans for the sector, the ministry, also, have territorial representations in each region. These regional delegations are charged with applying the ministry's tourism policy on the local level. Despite being under the central authority of the ministry, they still possess a margin of intervention locally such as supervising the sector in the region and get involved in collaboration with local stakeholders for the sake of developing the sector, walk through new tourism related investment, and spontaneous interventions in cases of regulation breeches concerning the functioning of tourism establishments.

As shown in Figure 3, the ministry consists of three main departments: strategy and cooperation; department of regulations, development, and quality; and department of resources and formation. The ministry does not project touristic promotion directly; rather, it collaborates in developing promotion strategies with its two main affiliates; the ONMT and the SMIT

\section{The ONMT}

A public institution, with administrative character, created in 1918, and acted since then as a key player in the Moroccan tourism sector; its mission is to promote and market the product 'Morocco' both at the national and international level. It has been assigned, in addition, the creation, the development and the management of facilities that contribute to the development of tourism, including accommodation infrastructure.

The commercial dynamism, of which the promotion strategy is an essential component, was an important link in Vision 2010 with the objective of "restoring the competitiveness of Morocco's destination and product". In this sense, it was agreed to restructure the entire promotion system with the aim of developing, in consultation with professionals, a more creative and responsive promotional policy.

In order to promote the notoriety of the destination 'Morocco' in the markets carried out by the strategic positioning of the sector, the ONMT set the objective of revising its promotion strategy in the direction of articulating it around "product", especially seaside and cultural product, instead of "destination". The review of marketing and communications strategies raised comments related to the development of marketing plans, the process of allocating promotional budgets, and the implementation of these marketing plans. 
Figure 3. Tourism Ministry Structural Hierarchy

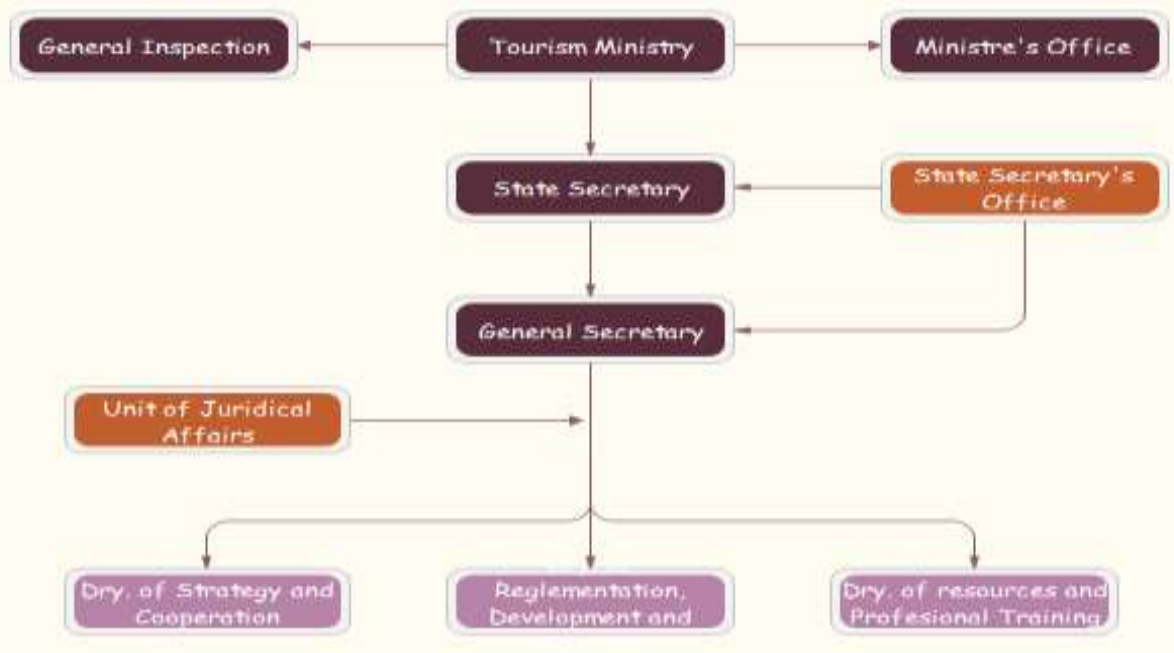

Source: Author.

ONMT's marketing and communication plans are a reproduction of the elements drawn at the level of the strategic plans. Indeed, they contain only summary elements such as the number of contracts to be concluded with Tour Operators at the level of each market, the number of fairs on which the ONMT intends to be present as well as the media to be used for institutional communication. The promotion activities to be deployed at the level of each market have also undergone a clear change compared to the marketing plan adopted initially with the start of Vision 2010, particularly for Italy, the United Kingdom and the Gulf countries in terms of institutional communication that was not originally planned.

Nevertheless, important tourism market niches, whose potential is indisputable, could have contributed positively to the said performances if they had received a particular interest. These are Moroccans Living Abroad (MRE), domestic tourism and "Meetings, Incentives, Conferencing, Exhibitions" (MICE). With regard to MREs, whose share of total overnight stays did not exceed $0.3 \%$ in 2012, the ONMT did not undertake any measures in the sense of an understanding of their profile, their tourist behaviour, their expectations and perceptions of holidays in Morocco and the possibility of converting them to the consumption of tourism products.

Under this pressure of taking Moroccan tourism to a better position, and in order to keep in line with the recent changes in the global tourism industry. The office announced in June 2015 that it is undertaking a deep change in its internal organisation structure. The new organization chart is structured around three main activities, namely the strategic activities relating in particular to the definition of Morocco's brand strategy, the operational implementation of product strategies, and the coordination of all communication actions. For their part, the operational activities consist of the distribution of the Morocco brand in the various markets, the animation of delegations abroad while guaranteeing a single interlocutor for the provision of resources, adding that the support activities represent the main 
provider of financial, material and human resources and a guarantee of respect for the financial balance of the Office.

The restructure consisted of the creation of two new internal departments; as for the "Digital \& New Technologies" Department, it will be in charge of the integration of new technologies in the promotion strategy of the destination Morocco to offer a better visibility on the Internet. While "Morocco and internal tourism" department will have as main missions the participation in the definition of the strategic orientations of Morocco's brand and the development of a deep knowledge and an expertise of the product Morocco. The general orientation of the new structure tends to focus on participation in the definition of product positioning, the development of awareness and the image of domestic tourism and the development of a permanent contact with tourism sector professionals in Morocco, local authorities and the press.

\section{$\underline{\text { The SMIT }}$}

A public institution created in December 2007 by the Moroccan State with the aim of implementing the strategy of development of the tourist product in Morocco (see Figure 4). It emanates from the need to bring out a public actor in charge of the construction of the tourist product. In addition to carrying out new major projects on behalf of the State or legal entities governed by public law throughout the national territory, the SMIT has other mission such as:

Conducting studies for the implementation of tourism development strategy adopted by the public authorities.

Market studies for the definition of the different product ranges.

Preliminary studies for the identification of tourist areas and those concerning the development and implementation of plans for the development of tourist areas.

Carry out actions of promotion and tourist development with the investors and assist the public authorities in the choice of the candidatures with the calls for tenders.

In an international competitive context between tourist destinations, differentiation has become one of the major challenges of development. The SMIT states, on its official webpage, that it places attractiveness at the heart of its concerns with the aim of making the most of the assets of each touristic region to make it a true competitiveness cluster. Raising various challenges for the Moroccan tourism sector namely design the offer, identify and highlight tourist sites of interest, mobilize land, guide public and private investment, support investors and tourism operators, facilitate their development in Morocco. 
Figure 4. SMIT Internal Organization

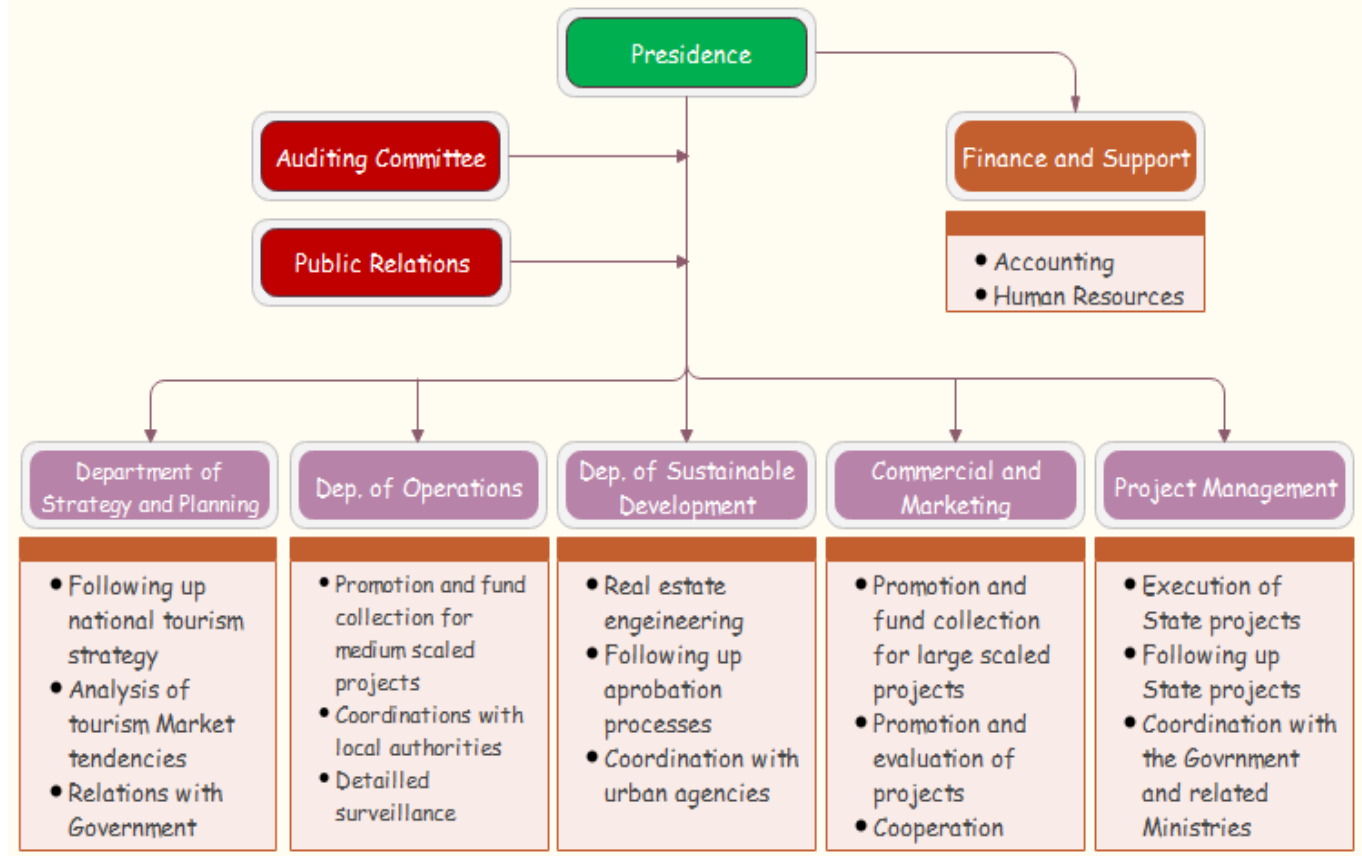

Source: Elaborated by author based on: smit.gov.ma/fr/notre-organisation/.

Throughout the years, the SMIT accumulated a solid experience in structuring and assembling flagship projects. It provides private investors, local authorities and various public stakeholders with a team of professionals and a personalized and quality service offering to support them since the initial conception of their project until they are put into operation (Figure 4). Its main objective is to support these partners to increase their economic competitiveness and thus contribute to the success of their development. SMIT's intervention focuses on the strategies of tourism projects, by defining and implementing large-scale promotional actions able to support the attractiveness of the Morocco destination as a tourist investment hub. The SMIT, also, has some considerable presence on the international level. Taking advantage from its network of international partners, it seeks to place Morocco at the centre of global tourism investment and thus make the country a key destination for tourism investments.

\section{$\underline{\text { Regional Centres of Investment (CRIs) }}$}

The CRI (Centre Regional d'Investissement) creatred by the state in order to pursue its policy of regionalization of business creation and investment projects since October 2002. This entity has taken place at the heart of each region and provides both consultation and support in the steps that entrepreneurs or investors must take. It displays a proximity character by remaining available at any time and a professional one by participating effectively in the implementation of projects. Its main roles are business creation help, assistance and investment projects, maintaining and developing existing investments, improving the attractiveness of the region to investments in sectors with high potential. The CRI is above all a 
partner for any project leader in Morocco. Figure 5 shows that structurally speaking, it consists of two main departments that form the core operation the CRIs perform nationally for help desk for starting businesses as a unique interlocutor of contact for all business starters/project holders; or the Investment Assistance Division which provides investors with all the useful information for regional investment; study all requests for administrative authorizations; and prepares all necessary administrative acts to the realization of investment projects.

Figure 5. Casablanca Regional CRI Organization

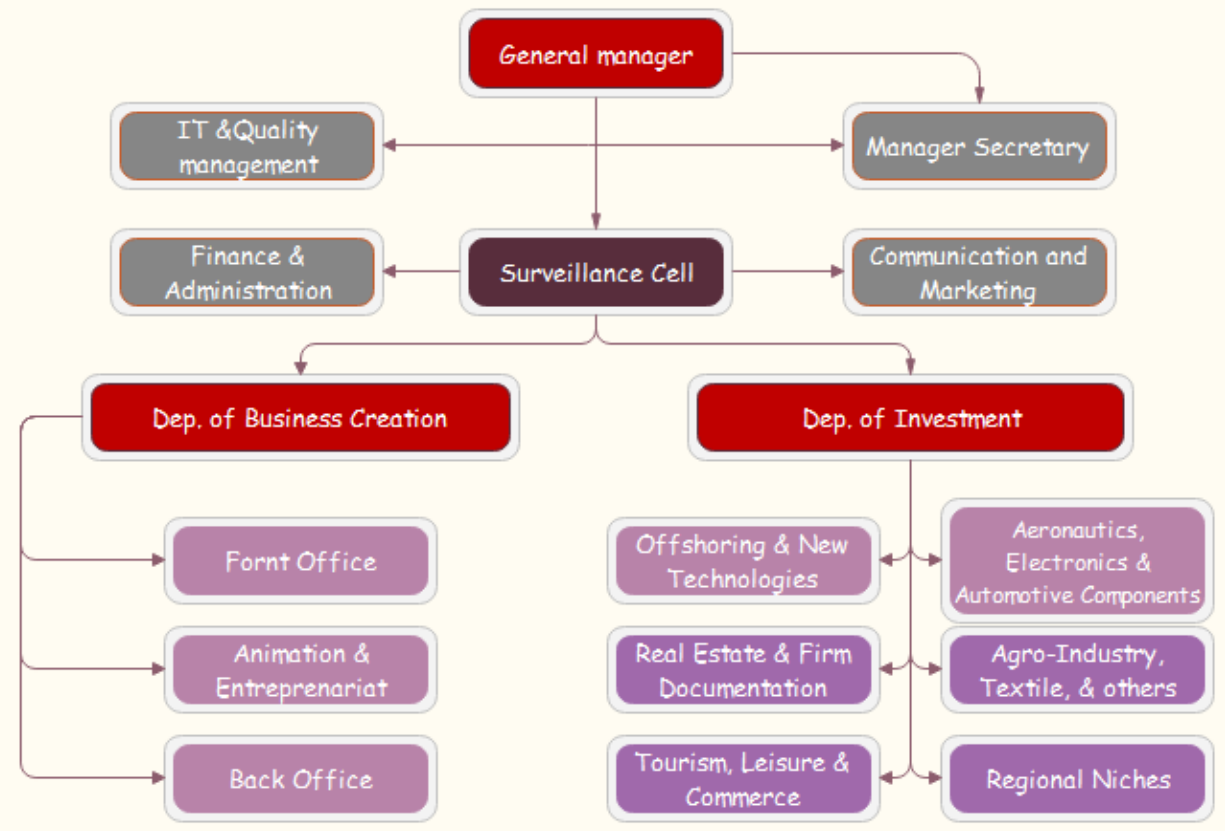

Source: Elaborated by author based on Source: casainvest.ma.

Investors willing to operate in the country on its different regions can find at the correspondent CRI alliance and partnership. In this public institution, necessary information for the creation of a business or investment in the region and a valuable help is presented. The CRI in Morocco is an intermediary entity between the project manager and the administrations that enables him to guarantee the creation of the enterprise. As part of the assessment of the experience of these centres, significant results were recorded at the level of business creation, particularly in the reduction of creation time. Court of Auditors (financial jurisdiction provided mainly responsible for monitoring the regularity of public accounts of the State), notes in a report, published in 2015, that several internal and external constraints that did not allow these entities to achieve the objectives assigned to them, including the adoption of action plans specific to each one. In addition, the report points to the lack of a special status of CRI staff, the existence of financial resources dependent on state subventions, the lack of follow-up of the companies created, and a limited role of CRIs in the implementation of national policies at the local level. The report, also, mentions the inadequacy of the IT interconnection of CRIs with their partners, the limited representation of administrations within the interlocutor and the absence of a single system for the 
payment of creation costs, as well as a legal framework that governs the Regional Investment Commission.

\section{$\underline{\text { National Confederation of Tourism (CNT) }}$}

Created in 1995, its main mission is to bring together all the tourism professions and contribute to the reinforcement of the structures of the various professions for greater efficiency and participation at the regional level namely Regional Federations of Tourism (FRT). Initially, the CNT was under the supervision of its mother federation, the CGEM (Confédération générale des Entreprises du Maroc), of which it was externalised since 2007 but remains statutorily attached to it. The CNT acquires a new ambitious structure turned towards its members: Regional Federations of Tourism) and National (National Federations of Tourism Professions). The following are the seven National Federations of Tourism professions included in the confederation: 1) National Federation of Hotel Industry; 2) National Federation of Moroccan Travel Agencies; 3) Association of Touristic Investors; 4) Federation of car rental companies without a driver in Morocco; 5) National Federation of Restaurants owner; 6) National Federation of Tour Guides and Mountains Guides; 7) National Federation of Tourist Transporters. The CNT designates its intervention in the sector on three main strategic axes; the strategic interlocutor of the entire sector to the public authorities and to all decision-makers; achieving the deployment of the 2020 vision; provide real services to members.

\section{$\underline{\text { Travel Agencies (Tour Operators) }}$}

One other of the most vital actors contributing to the national tourism sector is the network of Tour Operators (TO) providing trips and circuits services along with accommodation and other leisure products. These agencies could be categorised to many sets according to their nationality (national/foreign), operating cities, and provided products. In their majority, the present ones are the national TO focusing their products on the desert and imperial cities. In general, these are the product most acquired by tourist arriving to Morocco. Within this network, a set of criteria might affect the each TO's sales on the market. These could be product type, pricing, operating cities, and coherence or variety of the circuits. The major tour operators in the country may be found in the table below (Table 1).

\section{$\underline{\text { Hotel Industry }}$}

The hotel industry or accommodation services providers in general follow the same distribution logic of TO across the country. Large or international hotel chains are focused on Marrakech and Agadir, which both contains 46\% of the total accommodation capacity of the country (Tourism Ministry 2017). The categories distributed on the two cities may differ from high-end luxury resorts to humble houseguest or small-scale apartments. The most represented hotel chain in Morocco is, with no doubt, the French group Accor (which is dominant in luxury 
as well as in low-cost category). This group also manages other subgroups that are considered of its brand too such as: Ibis, Fairmont, Banyan Tree, L'univers Sofitel, Pullman, etc. across the major Moroccan cities (Marrakech, Agadir, and Casablanca) where the majority of accommodation capacity can be found. To illustrate more on this point, detailed information concerning dominant hotel chains can be found in Table 2 below.

Table 1. Major Tour Operators in the Country

\begin{tabular}{|c|c|c|}
\hline $\begin{array}{c}\text { Tour } \\
\text { Operators }\end{array}$ & Operating cities & Products \\
\hline \multicolumn{3}{|c|}{ National Travel Agencies } \\
\hline $\begin{array}{l}\text { Aventure } \\
\text { Berebere }\end{array}$ & Marrakech & $\begin{array}{l}\text { +Tours for group of people, a family, individuals (from } 2 \\
\text { people), even travel agencies, tour operators. } \\
\text { +Trekking circuits all around south and south-east } \\
\text { Morocco, } 17 \text { different circuits. } \\
\text { +Thematic tours such as } 4 \times 4 \text { circuits, Riyads-Hotels, } \\
\text { Autotour, Family Stay, etc. }\end{array}$ \\
\hline $\begin{array}{c}\text { Amaris } \\
\text { Voyages }\end{array}$ & Marrakech & $\begin{array}{l}\text { +Five categories of travel. Trekking circuits, Family } \\
\text { Travel, School Travel, Solidary Travel, and Nature- } \\
\text { Culture Travel. }\end{array}$ \\
\hline Top Desert & $\begin{array}{l}\text { Erg Chigaga, Erg } \\
\text { Chebbi and Erg } \\
\text { Lihoudi }\end{array}$ & $\begin{array}{l}\text { +Private transportation, camel trekking, sandboarding, } \\
\text { events organization. } \\
\text { +Private tours to the Sahara desert and to all-important } \\
\text { Morocco destinations. }\end{array}$ \\
\hline $\begin{array}{c}\text { Atlas } \\
\text { Voyages }\end{array}$ & $\begin{array}{l}\text { Marrakech, } \\
\text { Agadir, and } \\
\text { Essaouira. }\end{array}$ & $\begin{array}{l}\text { +Each destination, the main hotels in the city and their } \\
\text { main accommodation offers. } \\
\text { +Organised trip to south Morocco + Days circuit between } \\
\text { Ouarzazate and Merzouga cities inculing food, } \\
\text { accommodation and may other cultural activities. }\end{array}$ \\
\hline $\begin{array}{c}\text { Majestic } \\
\text { Tours }\end{array}$ & Rabat & $\begin{array}{l}\text { +Travel packages to Istanbul, Cairo and Dubai. } \\
\text { +Three-days circuit 'Marrakech - Terres D'Amanar - } \\
\text { Ourika - Oukaimeden' as product for Moroccan } \\
\text { Destination. } \\
\text { +'Excurssion' which consisits of circuits between various } \\
\text { Moroccan cities; Agadir, Marrakech, Casablanca, Fes, } \\
\text { Ouarzazate, Essaoouira, Tanger, Rabat, etc. }\end{array}$ \\
\hline $\begin{array}{l}\text { Marisar } \\
\text { Manar } \\
\text { Travel }\end{array}$ & $\begin{array}{l}\text { Rabat, } \\
\text { Casablanca, and } \\
\text { Marrekech }\end{array}$ & $\begin{array}{l}\text { +Easter Holidays which is a } 9 \text { days/ } 8 \text { nights circuit } \\
\text { organised between the cities of Marrakech - Ouarzazat - } \\
\text { Tinghir - Merzoga - Midelt - Ifrane - Fés - Meknes - } \\
\text { Rabat - Casablanca. } \\
\text { +Athentic Desert, } 8 \text { days/7nights tour including the cities } \\
\text { Marrakech - Ouarzazate - Zagora - M'hamid El Ghizlane. } \\
\text { +Desert and Sea another } 8 \text { days/7nights circuit focusing } \\
\text { on the seaside. } \\
\text { +Morocco Tour } 15 \text { days/14 nights visiting } 16 \text { cities: } \\
\text { Casablanca - Rabat - Tanger - Tetouane - Chefchaoune - } \\
\text { Meknes - Volubilis - Fes - Erfoud - Rissani - Zagora - } \\
\text { Ouarzazate - Taroudant - Agadir - Essaouira- Marrakech. }\end{array}$ \\
\hline $\begin{array}{c}\text { OLE } \\
\text { Voyages }\end{array}$ & Dakhla & $\begin{array}{l}\text { +'Dakhla Discovery'. A four-days stay at the Atlantic } \\
\text { city known for its surfing shores. } \\
\text { +Three circuit programs featuring Merzouga and } \\
\text { Ouarzazate mainly. }\end{array}$ \\
\hline
\end{tabular}




\begin{tabular}{|c|c|c|}
\hline \multicolumn{3}{|c|}{ Foreign Tour Operators } \\
\hline Fram & $\begin{array}{l}\text { Marrakech, } \\
\text { Casablanca }\end{array}$ & $\begin{array}{l}\text { +Local receptive, responsible for ensuring all } \\
\text { logistics (Organization of stays, group management, } \\
\text { home, animation, etc.) in France, Morocco, Tunisia } \\
\text { and Senegal. }\end{array}$ \\
\hline $\begin{array}{l}\text { Look } \\
\text { Voyages }\end{array}$ & $\begin{array}{c}\text { Major } \\
\text { Moroccan } \\
\text { destinations }\end{array}$ & $\begin{array}{l}+ \text { Different tour covering the major cities of the } \\
\text { country with numerous options in tour duration and } \\
\text { quality. }\end{array}$ \\
\hline $\begin{array}{l}\text { Thomas } \\
\text { Cook }\end{array}$ & $\begin{array}{c}\text { Marrakech, } \\
\text { Agadir, and Fez }\end{array}$ & $\begin{array}{l}\text { + The stretched streets of Old Fez, as well as hiking } \\
\text { in the Rif Mountains. } \\
\text { +Tours in south of the country to explore the } \\
\text { product desert. Its most used trips are the } \\
\text { + Short ones between Marrakech and Agadir due to } \\
\text { the potential of the two cities and their fame among } \\
\text { tourist as the most wanted destinations in Morocco }\end{array}$ \\
\hline $\begin{array}{l}\text { Nouvelles } \\
\text { Frontiers }\end{array}$ & $\begin{array}{c}\text { Moroccan } \\
\text { imperial cities }\end{array}$ & $\begin{array}{l}\text { It offers many } \\
\text { +Circuits destined to European visitors in general } \\
\text { and especially French. } \\
\text { +The tours are varied between } 4 \times 4 \text { tours between } \\
\text { Moroccan imperial cities with round flights, } \\
\text { accommodation, and meals included. The pricing } \\
\text { policy is based on the European model since it is } \\
\text { destined to Europeans. }\end{array}$ \\
\hline
\end{tabular}

Source: Author.

Table 2. The Major Dominant Hotel Providers in Morocco

\begin{tabular}{|l|l|}
\hline Hotels & \multicolumn{1}{c|}{ Desciption } \\
\hline Louvre & $\begin{array}{l}\text { The Golden Tulip hotels: Present in Morocco since 2006, Louvre } \\
\text { Hotels Group currently has 7 establishments, including 6 Golden } \\
\text { Tulip and 1 Tulip Inn, managed within a local structure. the Group } \\
\text { has set up a real strategy of tailor-made development, in both in the } \\
\text { economic hotel and in mid-range and luxury hotels. The Group has } \\
\text { plans to establish its first-class brands in the major economic } \\
\text { centres of the country (Casablanca, Marrakech, Rabat, Tangiers, } \\
\text { and Fez) as well as in medium-sized cities like El Jadida, Meknes } \\
\text { and Oujda to address both the international and local clientele. }\end{array}$ \\
\hline Kenzi Hotels & $\begin{array}{l}\text { The leading Moroccan hotel group, offering excellent service and } \\
\text { high-profile professionalism in the Moroccan hotel industry. The } \\
\text { group entered the Moroccan market to compete on the same level } \\
\text { with foreign hotel chains in luxury products. As stated on the group } \\
\text { website, its vision is to be the hallmark, the ultimate reference and } \\
\text { the landmark of fine hotels in today's Modern Morocco; to be } \\
\text { known as a well-reputed brand, its standards of excellence } \\
\text { consistent in all locations, well known and prominent for its high- } \\
\text { quality service and its excess of guest experiences and gastronomic } \\
\text { art. The group is present with 10 establishments distributed between } \\
\text { Casablnca, Marrakech, Tanger, Agadir and Errachidia. }\end{array}$ \\
\hline
\end{tabular}




\begin{tabular}{|c|c|}
\hline $\begin{array}{l}\text { Relais and } \\
\text { Châteaux }\end{array}$ & $\begin{array}{l}\text { High-end French-style hotels established in 1954, an association of } \\
\text { more than } 550 \text { landmark hotels and restaurants operated by } \\
\text { independent managers, chefs, and owners who perform under the } \\
\text { name of the brand. The group uniquely formulates its hotels } \\
\text { services in parallel with the country's culture values. It offers an } \\
\text { introduction to a lifestyle inspired by local culture. They stress on } \\
\text { protecting and promoting the richness and diversity of the world's } \\
\text { cuisine and traditions of hospitality as well as preserving local } \\
\text { heritage and environment. It has } 5 \text { establishments in Fes, Rabat, } \\
\text { Essaouira, and } 2 \text { in Marrakech. }\end{array}$ \\
\hline $\begin{array}{l}\text { Hyatt Hotels } \\
\text { Corporation }\end{array}$ & $\begin{array}{l}\text { A luxury hotel in the Old Medina of Casablanca, The hotel has a } \\
255 \text { rooms, including } 223 \text { deluxe king and twin rooms, } 11 \text { junior } \\
\text { suites, } 19 \text { executive suites and } 3 \text { royal suites, and } 8 \text { conference } \\
\text { rooms accommodating from } 20 \text { to } 400 \text { people. Its restaurants, such } \\
\text { as Cafe M, Dar Beida, Bissat and the outdoor Les Bougainvillées } \\
\text { cater in Moroccan, fusion or Parisian cuisine. They have a special } \\
\text { line of accommodation called 'King Rooms' cover } 31 \text { square metres } \\
\text { with extreme luxurious equipments and privelages intended to VIPs } \\
\text { and high-profile guests like politicians and diplomatic bodies. }\end{array}$ \\
\hline $\begin{array}{l}\text { Mandarin } \\
\text { Oriental }\end{array}$ & $\begin{array}{l}\text { Located in the heart of } 20 \text { acres of Moroccan gardens and olive } \\
\text { groves, Mandarin Oriental, is a hotel five stars located just minutes } \\
\text { away from Marrakech city centre. With its excellent facilities and } \\
\text { world-class cuisine, it allows to discover all the country's qualities. } \\
\text { This hotel brand is only present in Marrakech but it's one of the } \\
\text { most famous accommodation facilities in the country. It usually } \\
\text { hosts the national and international conferences, sports events, and } \\
\text { different festivals. its view on the Atlas Maintains in the } \\
\text { background gives it such a privilege. Its offer varies from luxurious } \\
\text { villas, spacious suites, and exceptional spa. Along with a wide } \\
\text { choice of innovative restaurants. }\end{array}$ \\
\hline $\begin{array}{l}\text { Hivernage } \\
\text { Collecion }\end{array}$ & $\begin{array}{l}\text { This hotel collection includes five stars: the Hivernage Hotel \& Spa, } \\
\text { The Pearl Marrakech, Riad Marrakech by wintering and Palm Villa } \\
\text { by Hivernage. It offers an exclusive offer and terraces offering } \\
\text { views of the medina, the Atlas Mountains and ancestral monuments. } \\
\text { Located in the centre of the city, the prestigious hotels of the Group } \\
\text { Winter Collection are high-end of Moroccan luxury hotels. The } \\
\text { various units of the group are in the neighbourhoods and the most } \\
\text { exclusive places in the Kingdom. The Winter Collection Group also } \\
\text { offers world gastronomy restaurants that are distributed on major } \\
\text { imperial cities of the country. }\end{array}$ \\
\hline $\begin{array}{l}\text { Angsana } \\
\text { Riads } \\
\text { Collection }\end{array}$ & $\begin{array}{l}\text { A sub brand of the Banyan Tree Holdings Limited which is a large } \\
\text { international tourism investments group based in Singapore. } \\
\text { Originally from Thailand, the company operates more than } 26 \\
\text { luxury hotels and resorts, } 65 \text { spas, } 70 \text { retail outlets and } 3 \text { golf } \\
\text { courses worldwide under the brand names Banyan Tree and } \\
\text { Angsana. In Morocco it is present as Agsana Riads in major } \\
\text { Moroccan cities (Marrakech, Rabat, Agadir, etc) with } 10 \\
\text { establishments in total. }\end{array}$ \\
\hline
\end{tabular}

Source: Elaborated by author. 


\section{Promotion Channels}

Once the promotion strategy is drawn, the actors included (private and/or public) tend to establish a work plan based on the drawn strategy guidelines. Depending on the nature and function of each actor, their intervention in terms of projecting a certain promotional material may vary. In addition, the techniques used to transmit the promotion of the destination may differ largely. This section highlights the main channels through which promotion actors project their promotional image. This projection is executed principally on three levels; 1) direct information, 2) public relations, and 3) touristic advertisement.

1. Direct information refers to the general and basic information about a given destination available for tourists and easily accessed. It could be acquired at tourism information centres that represent a permanent form of information to the public. This presentation could be done through engaging in interaction with visitors, animation of the visitors' in parallel activities while presenting the destination product, or by facilitating the purchase of stay/service to visitors. By all means, this channel is the most traditional one but still the most reliable in third world destination due to lack of modern technologies used in the process.

a. Moreover, direct information about a destination could be found also in documentation tools/ tourism diffusion. This includes informative brochures and folds made at visitors' disposal at either booking points or while on arrival. In addition, Mailing old clients or potential new ones, could be diffused in travel agencies, tourism offices, or at national representation in foreign countries.

2. Public relations with similar importance as information projection or advertisement, PR inside tourism must be planned and coordinated with other promotion forms, which touch the public directly, or with a press intermediate using read, spoken, or visual press. Big tourism enterprises use this method. Another way of using press as promotion channel could be aired interviews, press conferences, or even journalists travel.

a. Direct relation with the public without involving cooperation of the press, so that many promotion actors could be directed to other opinion formers. These direct promotional forms could be many and diverse such gastronomy, diffusion of static or animated image (movies, expositions.).

3. Touristic advertisement, like any other advertiser, tourism ones should follow the same strategy based on five crucial decisions while projecting their destination image.

i) Theme: the offer must seek, in a persuasive manner, a simple message and within the possible rather than a choice of arguments or propositions. It must take into consideration that a 
potential client does not excel at choosing between highly varied propositions.

ii) Target: On different markets, where touristic accommodation competition is intense, product suppliers seek to conquer new potential clientele. These suppliers, often, focus more on clientele adaptation to their products sections more than the preadaptation of the product to fit different clienteles. Market study in this case is conducted only to sensitive points to tackle in potential clients, since the clientele range is already known to the suppliers.

iii) Support: the choice of collaborating media (establishment, TV channel, Radio station...) is carried out considering the level of pricing process, capacity of product supply, and the mode of commercialisation applied by the competitors in the same aspect. However, knowing the precise features of the clienteles group such as dominant gender, age, economic status... could be crucial in the choice of marketing support.

iv) Campaign: the preparation of a promotion campaign should take in consideration, imperatively, the projection timeframe. For instance, the period and duration of campaign, frequency and emission dates should be performed in parallel with high seasons or most busy months of the year. These parameters are crucial in determining the success of the campaign. It really relies on the precise knowledge of the potential clientele.

v) Announcement (Emission): focusing on the good pricing, it must be stated the most important feature. It could be also useful to use precise facts and avoid generalisation or other common used ones, the idea here is to be special, unique, attractive. Not to mention the creativity in product projection and offer variation. The emission must focus, more importantly, on the best argument the supplier has and make it the leading motive.

These techniques are, in general, the ones deployed actually on the promotion in the Moroccan tourism sector. However, they might be used differently depending on the nature and function of the actors using them. However, the promotional material is conveyed through various distribution channels such as travel agencies, trade and tourists exchange, professional associations, press releases, web-based portals.

\section{Promotion Techniques}

Since the Moroccan state, in the tourism development process, acts as a planner, manager, and promoter; it is the main actor who is in charge (directly or indirectly) of the realisation of vision 2010 objectives. Among the main points of this vision is the promotion of destination Morocco with diversified product and to 
new markets. The initial action plan (2010) concerning promotion was focused on the following points:

- Product: triple classified accommodation capacity replying to international standards

- Transportation: activate the open-sky policy and open various new airlines with European capitals.

- Marketing: communication, commercialisation, adapted and efficient promotion policy. Repositioning of destination Morocco. Anticipation on the market of responsible tourism programme.

- Institutional organisation: creating organs of consultation and coordination between public and private sector actors; on regional and national level.

- Formation (professional training): professionally prepare 72,000 qualified personnel for the national tourist reception.

- Tourism environment: applying a set of general measurements to enhance tourist reception (airports, indication system, and access to information).

- Sector restructuration: Quality responsible and sustainable tourism

The ONMT (Office National Maroccain du Tourisme) is the main (public) promoter of tourism in the country. Its main mission is the promotion and Marketing of destination Morocco locally and internationally. The office follows a triple strategy in order to achieve the points mentioned above: 1) Product strategies: hard focus on seaside segment, by extending the seaside offer to a more diversified one and distributed as well on the Mediterranean coast consisting mainly of building new resort such as in Saidia, Alhoceima, Tetouan, Tangier. Surely, this will go in parallel with the repositioning of cultural product to make a more complete one and representing the real Moroccan potential. 2) Price strategy: improve relationship quality/price of destination Morocco; this policy suggests coordinated pricing process between professional conventions, and pricing reference network. Pricing quality coordinated with quality labels, as part of the legislative and regulatory provisions, the establishment of a quality label for all tourist-oriented businesses located in tourist development zones. 3) Promotion strategy: restriction of promotion scheme, restructure the whole of the operative part of the promotion of the destination with the objective of designing, in consultation with professionals, a policy of promotion more creative, responsive and adapted to the needs. Strengthen the OMNT's financial means and refocus the activities on promoting the image of Morocco abroad. Restructuring the entire tourism tax system so that collected taxes can be invested into tourism promotion. Charge the costs of staff trained under the OMNT supervision to ministry. Restructure the OMNT by amending its denomination and developing its mode of operation, to associate representatives of the profession into decision-making bodies.

As an ultimate objective, the state increased the promotion budgets by creating a promotion fund managed by the ONMT and powered by the tax of tourism promotion and the State budget with participation of the private sector in proportions to be defined on future agreements between all parties. The set 
objective was an annual share of 500 million dirhams (45 Million $€$ ) in the horizon of 2020, exclusively intended for the promotion. The state reached an agreement between different implied actors in the sector on the need to schedule this effect an increase of the product of the TPT (Taxe de Promotion Touristique) and predict the contribution of other institutions (private or public) benefiting from tourism revenues.

\section{Discussion}

Since the late 1990s, Morocco started to empower tourism as an economic levitator for the country (Sbai 2012). This process of bringing tourism to the front of the economic situation started much earlier than that. Its very first aspects were implanted as soon as the dawn of independence (Berriane 2002), with the creation of the Sherefian committee of tourism as the first Moroccan public institution charged with tourism. This committee will be transformed later to the ministry of tourism (Stafford 1996).

However, this long turn in the Moroccan tourism policy from a neglected sector to one of the main economic pillars of the country witnessed various ups and downs through its progress line. This progress line can be divided into many different periods. Almeida and Chahine (2016) divide it into three periods: 1) preFordist starting from after independence in 1956 when the majority of public investments were focused on agriculture and water infrastructure. For tourism, in this period, there were few resorts creating plans in the north and historical cities as part of the Triennial Plan; 2) Fordist period which started in the early 1970s, there was a shift in the public tourism policy towards attracting mass tourism. Promotion agencies were created to target international tourists and especially European market. However, this period went through a critical drop in tourists due to the Gulf War and other political/economic events in the area. This situation led to start the privatization process of considerable public supply accommodation; and 3) post-Fordist, with the beginning of the new monarchy period in 1999, tourism was put in priority for the economic development of the country. Public policies were pointed towards creating strategic plans that focuses on international investments and liberating air space and the creation of large holiday resorts. This new policy direction was translated later to what is known as the major tourist development strategy in the country, i.e. Vision 2010 and vision 2020 in continuation.

Despite the considerable position of Morocco destination among its regional competitors, the ambitious objectives set to be realised by the end of 2020 (Vision 2020) are still stuck to the previous vision 2010 expectations. After more than 7 years of its completion, tourists' arrivals are still hanging in the 10 million interval. However, the surrounding or external circumstances affected to some extent the growth of the Moroccan tourism sector, especially for European countries given the fact that Europe is the first tourist transmitter to Morocco. The late economic crisis back in 2008/2009 affected severely European investment in the country. Many corporations had to sell or withdraw their shares in resort projects that 
belonged to Plan Azur (2010 and 2020). Also, the latest terrorist attacks in various European cities (Paris, London, Berlin, Brussels) led to spread fear among the public about visiting any country in the region; even though Morocco marked a clean security record during the last decade (since the last terrorist attacks in Casablanca 2003). This wrong idea formulated to the European public is due to the misleading media propaganda. The non-efficient promotion of Moroccan destination to those areas allows those wrong ideas of chaos and insecurity to spread quicker and wider. In addition to this factor, essential points that make promotion of the product Morocco inefficient.

The poor optimization of communications established by the ONMT has not managed to get into regional and international dynamics. There is no regionalization of promotion through the CRTs. In this context, Laws 1995 (cited in Cox and Wray 2011) proposed five key phases of destination marketing which ease the path to development objectives. 'diagnosis phase' in which destinations must assess the market situation through inspection of existing tourist facilities, identification of tourists' preferences and behaviours about the destination, and identification of competitor destinations. Then comes the "prognosis phase", which seems to have more futuristic view, regarding the planning of destination's development. The other three phases consist of setting objectives for the regional destination; implementing marketing strategy; and monitoring marketing performance. However, in the Moroccan tourism context we can notice the absence of some of these phases in the country's tourism marketing plans especially the first one (the diagnosis phase). This absence lays in the sector invariant facilities as well as the inconsistent competitive performance compared to similar product based destinations in the area.

In parallel with the external promotion efforts, the ONMT has also future plans to regionalize the touristic promotion; that is to say that the office will carry out this mission (the institutional image of destination Morocco) so that each region can execute the promotion and marketing of its own territory. Concerning the financial aspect, part of the budget drawn for the operation ought to stay at the ONMT and another will be transferred to the regions with the support of CRIs and sector professionals. The benefits for the regions from this regionalized promotion are the expected investments that will generate jobs. It is also the role of the regionally elected councils to promote their destinations and boost the economy of their regions.

Cox and Wray (2011) point out that destination marketing, in its traditional perspective, has focused on image creation and promotion aimed at achieving growth in domestic and international arrivals rates. Adding that recently carried out research tend to recommend more emphasis on adopting a sustainable marketing approach that combines sustainable destination management and development objectives. This approach explicitly suggests that destination marketing should act as a strategic tourism management tool which creates some kind of balance between the market objectives of stakeholders and the destinations sustainability. In addition, the World Tourism Organization (UNWTO 1999) proposed a sustainable model for marketing destinations. This model consists of generating a detailed record of existing tourism attractions and facilities of the 
destination as well as identifying potential competing destinations. Based on this perception, the UNWTO (1999) then recommends destinations to clarify the aspirations of local communities from tourism activities. These steps aim to develop a promotional strategy that seeks matching existing facilities with the needs of the market in question and the objectives of its local community.

Nevertheless, the ONMT, as the main promoter of tourism in the country, does not present a quantified assessment of its policy to professionals, whose performance is already shattered by incoherent promotion policy and weak marketing means especially for the seaside product for which competition is very strong. To tackle this point, the office started lately to project its promotional material for the destination Morocco using French media, according to the ONMT this campaign will allow promoting the Moroccan destination in general to achieve high performance and reaching in the French market. The priority markets to conquer in Europe are UK, France, Spain, Germany, Netherlands, Belgium and Italy. The office carried out studies to assess these markets and evaluate new tendencies, hotel industry actors must play along to win the concurrence.

In parallel, Buhalis (2000) and Prideaux and Cooper (2002) as cited in (Cox and Wray 2011) note that there are multiple actors involved in the destination marketing, and confirmed that destinations which are based on many products and attributes require consequently many marketing activities. For this sake, an efficient level of cooperation must be developed between private and public sector actors' within the tourism sector. This integrality is considered to be critical in the effectiveness and success of marketing strategy (McDonald 1999). In the same sense, the registered relative weak occupation rates in accommodation units might be due to the missing of this integrality in the marketing policy targeting customers rather than the product-market relationship.

From the big new strategies followed by the ONMT is the creation of a new digital directory (web-based) to go along the rise of internet in the tourism industry. This strategy is not only for international tourism but part of it will be dedicated to domestic tourism as well. This strategy is also based on the modernization of ONMT's functioning mode, human/financial resources management using advanced IT. Accordingly, the Tourism Ministry relies on social media to promote sustainable tourism in the framework of the celebration of the international year of sustainable tourism for development, and aims to sensitize the community about the notion of sustainability touristic in the country.

\section{Conclusions and Recommendations}

The current situation of tourism promotion in Morocco requires a general reorientation of the actual tourism policies. A deep understanding of the country's tourism potential including its strengths and weaknesses compared to its direct and indirect competitors in the area. The country promising potential is tied up by various structural and management challenges. These challenges could be easily overcome by innovative plans and retargeted interventions. Starting with a complete and general diagnosis of the Moroccan tourism sector and highlighting 
the most affecting factors, its full potential, and the best practice that could be carried out will be the best strategy. A key element here, after the identifying the sector fully, may be the identification of similar practices in competing destinations with similar potential.

Morocco must use competitive advantages over its direct competitors in the area currently, such as Turkey, Cyprus, Tunisia and Egypt. Therefore, Moroccan policymakers and tourism industry leaders ought to re-draw their management strategy to reach the maximum exploitation of the country's tourism resources. In this sense, many applicable steps could be taken into account like resetting the tourism image of the country - portrayed through the official promotional materials - via diversifying the offer to contain other promising products especially outside the typical imperial cities of the country. There is a considerable touristic potential in areas like the North of Morocco or the marginal areas of the Atlas with splendid natural resource. If correctly managed, these 'forgotten' regions could make a huge difference in the performance of the Moroccan tourism sector.

Marketing of tourism in Morocco still sticks with the same destination image created by first world agencies or worst from the colonial period. Even in some recent promotional media, they concentrate on the product desert as the main theme of the destination. The depiction of Moroccan tourism product in official promotional media is still highly superficial. It does not show the real identity of the destination. In some cases, the exhausting use of local culture elements for the sake of tourism led to some kind of reluctance towards their own culture compositions. For instance, in the city of Chaouen, the excessive exposition of cultural artefacts covering all the blue beautiful walls of the city, making it all about a large artefacts market. In this sense, from the image existing on the ground it seems that the Moroccan public policies have led to centring the touristic activity solely around the touristic product; totally neglecting the human factor. Absence of empowering of the Moroccan Man within the destination make the tourism activity appear as any normal trade with product and consumers.

This reorientation process requires a serious implication of all actors and stakeholders implied in the marketing of the destination Morocco. Both public and private sectors have to develop a shared vision that could function as a roadmap for a new promotion strategy that empowers the full-diversified potential of the country. To facilitate achieving this objective, some short- and long-term tactics and strategies should be deployed. Such as directed investments at improving the content and quality of the Moroccan promotional and marketing techniques and channels; also, a cooperative effort between the private sector and the public sector is needed in order to systematically promote the tourism and cultural image of Morocco through hosting well-orchestrated international fairs and exhibitions. Such a strategy should focus on improving the competitiveness of the different aspects of Moroccan tourism as a standalone destination generally, and its interior major sub-destination as the core competing product that will reset the country as a leading destination in the region. Finally, the Moroccan government must reconsider its commitment and national priority in relation to the tourism industry. 


\section{References}

Almeida F, Chahine S (2016) Evolución de la política turística y la intervención estatal. El caso de Marruecos [Evolution of tourism policy and state intervention. The case of Morocco]. Cuadernos de Turismo 38(2016): 13-37.

Baloglu S, McCleary KW (1999) A model of destination image formation. Annals of Tourism Research 26(4): 868-897. Doi=10.1016/S0160-7383(99)00030-4.

Beerli A, Martin JD (2004) Factors influencing destination image. Annals of Tourism Research 31(3): 657-681. http://dx.doi.org/10.1016/j.annals.2004.01.010.

Berriane M (2002) Les nouvelles tendances du développement du tourisme au Maroc [New trends in tourism development in Morocco]. In 13ème Festival International du Géographie de St Dié :1-15.

Cox C, Wray M (2011) Best practice marketing for regional tourism destinations. Journal of Travel \& Tourism Marketing 28(5): 524-540. DOI: 10.1080/10548408.2011.588112.

Del Bosque IR, San Martín H (2008) Tourist satisfaction a cognitive-affective model. Annals of Tourism Research 35(2): 551-573. Doi=/10.1016/j.annals.2008.02.006.

Echtner CM, Prasad P (2003) The context of third world tourism marketing. Annals of Tourism Research 30(3): 660-682. Doi=10.1016/S0160-7383(03)00045-8.

Echtner CM , Brent RJR (2003) The meaning and measurement of destination image: [Reprint of original article published in v.2, no.2, 1991: 2-12.]. Journal of Tourism Studies 14(1): 37-48.

Gummesson E (2002) Relationship marketing and a new economy: it's time for de-programming. Journal of Services Marketing 16(7): 585-589 doi=10.1108/0887 6040210447315.

Observatoire du Tourisme. (2015) Annuaire Statistique du Tourisme: Panorama des Performances Touristiques au titre de l'année 2015. Casablanca. Observatoire du Tourisme.

Gallarza MG, Saura IG, García HC (2002) Destination image. Annals of Tourism Research 29(1): 56-78. Doi=10.1016/S0160-7383(01)00031-7.

Govers R, Go FM (2004) Projected destination image online: website content analysis of pictures and text. Information Technology \& Tourism, 7(2): 73-89.

Govers R, Go MF, Kumar K (2007) Promoting Tourism Destination Image. Journal of Travel Research 46(15): 15-23. Doi=/10.1177/0047287507302374.

Kotler P (2000) Marketing Management. (Millennium edition, 10th ed). New Jersey: Pearson.

Lumsdon L (1997) Tourism marketing. London: International Thomson Business Press.

McDonald M. (1999) Marketing Plans 4th Edition. Butterworth-Heinemann. eISBN: 9780080569567

Ministère du Tourisme (2001) Strategie du Tourisme au Maroc: Vision 2010 [Tourism Strategy in Morocco: Vision 2010]. Rabat.

Ministère du Tourisme et l'Artisanat (2010) Departement du Tourisme: Vision 2020 Strategie de Developpement Touristique. [Tourism Development Strategy: Vision 2020]. Rabat.

Sbai L (2012) Evaluation du cadre juridique et institutionnel relatif à l'écotourisme et aux aires protégées au Maroc [Evaluation of the legal and institutional framework for ecotourism and protected areas in Morocco]. Rapport UICN.

Stafford J (dir.) (1996) Développement et tourisme au Maroc, Montréal, L'Harmattan.

Tasci ADA, Gartner WC (2007) Destination Image and Its Functional Relationships. Journal of Travel Research 45(4): 413-425. Doi=10.1177/0047287507299569.

UNWTO (2014) Tourism Highlights, 2014 edition. World. 
UNWTO (1999) Tourism Highlights, Published: 1999 eISBN: 978-92-844-0301-1

UNWTO (2015) Understanding Tourism: Basic Glossary. [Accessed 15 October 2017] Retrieved from https://bit.ly/1ki2UGS.

UNWTO (2017) Tourism Highlights, 2014 edition. 